\title{
ADMIRAL ELPHINSTONE AND THE CONQUEST AND DEFENCE OF THE CAPE OF GOOD HOPE, 1795-96
}

\author{
Thean Potgieter, Department of Military History, Faculty of \\ Military Science, Stellenbosch University \\ and \\ Professor Albert Grundlingh, Department of History, \\ Stellenbosch University
}

\begin{abstract}
Vice Admiral of the Blue the Honourable Sir George Keith Elphinstone (1746-1823) was appointed as commander of the British force dispatched to capture the Cape of Good Hope in 1795. As an experienced naval officer and a capable commander acquainted with the Cape and the Far East, he was the correct choice to command the expedition. Due to the strategic location of the Cape of Good Hope literally halfway on the sea route to the East - it was vital for maritime communications, and Britain had to ensure that the Cape did not fall into French hands. To secure a safe base on the sea route to the East, a British expeditionary force was sent to the Cape. The British task force arrived in False Bay on 11 June 1795 and when negotiations with the Dutch authorities at the Cape failed, a military campaign commenced that resulted in the capitulation of the Cape on 16 September 1795. In August 1796, when a Dutch squadron under the command of Rear Admiral E. Lucas anchored in Saldanha Bay, Elphinstone speedily neutralised the threat, forcing Lucas to surrender. After a very successful service period at the Cape, Elphinstone returned to Britain on 7 October 1796. He conducted the defence of the Cape with vigour and actively sought out his enemy, confirming British control of the Cape and the virtual impossibility of taking back the Cape with force of arms.
\end{abstract}

\section{Introduction}

Vice Admiral of the Blue the Honourable Sir George Keith Elphinstone, as he is known in South African history (Viscount Keith in the annals of the British Royal Navy) was one of the great British admirals of the late eighteenth century and the Napoleonic era. He commanded British fleets in various parts of the world and 
made an important contribution to the process through which Britain achieved naval mastery.

Britain regarded the Cape of Good Hope as vital for maritime communications due to its strategic location literally halfway on the way to the East, or India (the so-called "jewel in the imperial crown"). When the French Revolutionary War commenced in 1792 (France declared war against Austria in 1792 and against Britain and the Netherlands early in 1793), Britain was anxious about the security of the Cape sea route. Though the Cape was in Dutch hands, the British had to make sure that it did not fall into French hands. An expeditionary force under the command of Elphinstone was sent to the Cape in 1795 . When negotiations with the Dutch authorities failed, the Cape was forced to capitulate on 16 September 1795. Roughly a year later, when a Dutch squadron under the command of Admiral Lucas anchored in Saldanha Bay in August 1796, Elphinstone forced the Dutch to surrender and neutralised the threat to the Cape. During his tenure as naval commander at the Cape, Elphinstone proved himself a capable commander and played a crucial role in both the conquest and defence of the Cape.

The Royal Navy of the late eighteenth century was a large, competent and effective navy, with a good administrative system, experienced seamen and excellent leadership. ${ }^{1}$ Both the Dutch and the French, but especially the Dutch, had a strong maritime tradition which emphasised the global and economic value of maritime power, seaborne trade and a strong navy. The Dutch and French navies, however, had lost much of their former professionalism and glory due to the political turmoil of the age and found it difficult to maintain and deploy large fleets. The result was that they did not afford the same emphasis to maritime power and were not capable of utilising it with the same measure of success as the British. During this period, it was essentially the "wooden walls" of its navy that protected the British Isles as well as its global interest against powerful continental enemies, in Mahan's words “... those far - distant storm-beaten ships upon which the Grand Army never looked". ${ }^{2}$

In naval doctrine, effective command and control is understood as fundamental to the efficient deployment of maritime forces. In order to conduct operations with success, a clearly defined and flexible command chain is essential and forces must be positioned timely and with skill. Command is currently defined by the Royal Navy as "the authority granted to an individual to direct, co-ordinate and

1.

S.W. Roskill, The Strategy of Sea Power. Its Development and Application (London, 1962), p. 65.

2. A.T. Mahan, The Influence of Sea Power upon the French Revolution and Empire, 1793-1812 (London, 1892), p. 118. 
control military forces", while control includes the operational and tactical control of a commander as well as the "actual process through which the commander organises, directs and co-ordinates the activities of forces allocated to him". ${ }^{3}$ Despite the recentness of these definitions, they are appropriate to the function naval commanders such as Elphinstone performed.

Joint operations were very difficult during the late eighteenth century due to obstacles such as logistics, the embarkation of troops, intelligence, co-ordination and time scales. It probably is remarkable that, despite this, so many joint operations did succeed at the time. ${ }^{4}$ The British learned to master the techniques of amphibious warfare and to respect the vital value of planning and preparation during the Seven Years' War (1756-1763) and the American War of Independence (1775-1783). Troops and equipment had to be assembled and embarked, the organisation of the armed forces had to be maintained during the voyage, troops had to be properly commanded and moved with the assistance of the navy during the actual landings, while the navy also had to provide gunfire support, if necessary. Forces ashore then had to be supplied (with provisions, ammunition and equipment) from the ships. ${ }^{5}$ As early as 1763 guidelines to British officers already stipulated that when a landing site is decided upon, "the whole command is given to a Sea Officer who conducts them to the place of landing ....". ${ }^{6}$ Once the men were out of the boats and actually set their feet ashore, the Army commander took over command of the soldiers. A good working relationship between these commanders therefore had to exist throughout.

Many examples of poor command and control also exist in the history of the Royal Navy, and the Antwerp debacle of 1809 (in Elphinstone's time) is a clear example of a command and control failure. The Antwerp operation (the greatest British amphibious operation to that date involving 40000 troops) failed with heavy losses due to bad intelligence, the poor doctrinal grasp of the commanders and inadequate co-operation between naval and land forces. ${ }^{7}$ Yet, despite all the potential difficulties, British forces did achieve success at the Cape.

3. Directorate of Naval Staff Duties, The Fundamentals of British Maritime Doctrine (London, 1995), pp. 128-129.

4. M. Blumenson and J.L. Stokesbury, Masters of the Art of Command (New York, 1975), p. 249.

5. S. Foster, Hit the Beach. The Drama of Amphibious Warfare (London, 2004), pp. 11-12.

6. Quoted in S. Foster, Hit the Beach, p. 13 from a 1763 publication: J. MacIntire, A Military Treatise on the Discipline of Marine Forces when at Sea, Together with Short Instructions for Detachments Sent to Attack on Shore, p. 225.

7. Directorate of Naval Staff Duties, British Maritime Doctrine, p. 129. 
Perhaps command can be seen as an art to be mastered, requiring special knowledge, good intuition, intelligence, and reason. Commanding and motivating people in war, is an extremely complicated process and successful practitioners of the art of command were "a special breed of men, distinguished by strength, will and [often] flair". ${ }^{8}$

This article primarily deals with the role Admiral Elphinstone played in the occupation and defence of the Cape during 1795 and 1796. The British take-over of the Cape in 1795 and Elphinstone's action against an enemy fleet is examined with reference to the actions of the opposing sides and Elphinstone's conduct as a commander.

\section{The early naval career of George Keith Elphinstone}

George Keith Elphinstone, the fifth son of Charles, tenth Lord Elphinstone, was born on 7 January 1746 at Elphinstone Tower, near Stirling. ${ }^{9}$ He followed the example of two of his brothers by going to sea. At the age of sixteen he joined the HMS Gosport, commanded by Captain John Jervis (the later Earl St Vincent) as a midshipman. After the end of the Seven Years' War in 1763, he went to China on board an East Indiaman commanded by his elder brother (W. Elphinstone). In 1767 he again went to the East, this time with Commodore Sir John Lindsay.

Elphinstone was commissioned as a lieutenant in 1770, became a commander in 1772, and a post captain in 1775. During the American War of Independence he saw action against privateers and gained experience in joint operations by participating in a naval brigade during the occupation of Charleston. $\mathrm{He}$ gained recognition for his conduct and was afterwards mentioned in official dispatches. In January 1781, while in command of the HMS Warwick (50 guns), he captured the Rotterdam, a Dutch warship of equal size, in the English Channel. After the conclusion of peace, he remained ashore for ten years and served as a Member of Parliament for Dumbartonshire and Stirlingshire.

After the outbreak of the War of the French Revolution in 1793, he received command of the HMS Robust (74), sailing to the Mediterranean under the command of Lord Hood. He participated in the occupation of Toulon and distinguished himself

8. M. Blumenson and J.L. Stokesbury, Masters of the Art of Command, p. x.

9. A. Allardyce, Memoir of the Honourable George Keith Elphinstone KB.

Viscount Keith, Admiral of the Red (Edinburgh, 1882), p. 1. 
ashore by defeating a body of French soldiers while in command of a British-Spanish naval brigade. On returning to Britain in 1794, after the British were forced to evacuate Toulon, Elphinstone was knighted (Order of Bath) and was promoted to Rear Admiral of the Blue in July. He became a Rear Admiral of the White three months later and on 1 June 1795 (while at sea en route to the Cape), he was promoted to Vice Admiral of the Blue.

\section{The British conquest of the Cape, 1795}

As British interests in India grew, India became important for British prosperity, but the sea route that linked Britain with India was vulnerable. The Cape of Good Hope, located on the southern tip of Africa was literally halfway to the East and vital for maritime communications with the East, but it was in Dutch hands and usually well-defended during the oft-fought wars of the eighteenth century. Britain therefore became concerned about the safety of its maritime communications when war broke out.

After the French had successfully invaded the Netherlands late in 1794, the Stadtholder, William V, Prince of Orange, fled to England early in 1795 . The new Dutch State, called the Batavian Republic, became an ally of France and an enemy of Britain. Since the British feared the Cape might fall into French hands and become a base for French privateers, much anxiety existed amongst the directors of the English East India Company (EEIC). On 4 January 1795, Sir Francis Baring, Chairman of the Company, emphasised that the Cape is important for the refreshment of EEIC ships and added that whoever is ".. master of the Cape will be able to protect or annoy our ships". ${ }^{10}$ He requested the Secretary of State for War, Henry Dundas, to make an attempt on the Cape of Good Hope as they might surprise the defenders and it could easily be conquered - but he added, if the Cape is lost, there is no substitute. ${ }^{11}$

After war with the Netherlands had broken out, the British captured Dutch possessions all over the world, in the "interest of its own naval supremacy". ${ }^{12}$ As they were convinced of the crucial value of the Cape and afraid that the "feather in the

10. National Archive of the United Kingdom, formally the Public Record Office, Kew (hereafter NAUK), WO1/323, Baring - Dundas, 4/1/1795, pp. 1-2.

11. See the correspondence between Baring and Dundas in G.M Theal (ed.), Records of the Cape Colony from 1793 to December 1796, Volume I (London, 1897), pp. 19-23.

12. A. Allardyce, Memoir of the Honourable George Keith Elphinstone, p. 85. 
hands of Holland" would become a "sword in the hands of France", ${ }^{13}$ the British resolved to take control of the Cape. On the insistence of British politicians, the exiled Prince William of Orange wrote a letter to the Cape authorities (7 February 1795) requesting them to allow British warships to defend the Cape and to receive the British troops into the Fort as they would prevent a French invasion. ${ }^{14}$

Zealous preparations for an expedition to the Cape commenced immediately. Sir George Keith Elphinstone was appointed naval commander of the task force and "Commander in Chief in all the Indian Seas", with full powers to fight or negotiate depending on the circumstances. ${ }^{15}$ Elphinstone was a good choice and during the previous months Dundas had often consulted Elphinstone on operations in the Indian Ocean due to his service with the EEIC and the fact that he had been to China and India. Elphinstone was familiar with the severe sea conditions around the Cape of Storms, and he had the ability to plan and organise such a maritime campaign. The expeditionary force eventually sailed in three groups. The first ships to depart were under the command of Captain John Blankett (three third-rate ships of the line and a sloop), who promptly embarked Major-General Sir James Henry Craig and 515 soldiers of the $78^{\text {th }}$ Regiment. They actually managed to depart as early as 16 February.

Before his departure, Elphinstone thoroughly studied the state of affairs at the Cape, realising that an important issue would be to guarantee the paper money of the colonists. ${ }^{16} \mathrm{He}$ also arranged the naval details of the fleet, made provision for a winter campaign in Cape waters, and arranged for assistance from the EEIC as well as from the Governor-General and various governors in India. Due to the anticipated winter conditions around the Cape at the time the main force was set to arrive, it was thought difficult to rendezvous off the Cape. San Salvador (de Bahia in Brazil) was therefore chosen as the rendezvous point with the Army Commander, Major-General Alured Clarke, who would depart later. Elphinstone therefore made arrangements concerning Clarke's reception with the Portuguese governor of San Salvador and

13. M. Boucher and N. Penn, Britain at the Cape, 1795-1803 (Houghton, 1992), Blankett - Napean, 25/1/1795, p. 22.

14. G.W. Eybers, Select Constitutional Documents Illustrating South African History, 1795-1910 (New York, 1918), Grenville - York, 1/2/1795, pp. 1-2 and Order from the Prince of Orange to the Governor of the Cape of Good Hope, 7/2/1795, pp. 2-3.

15. A. Allardyce, Memoir of the Honourable George Keith Elphinstone, pp. 8586.

16. W.G. Perin, The Keith Papers. Selected from the Letters and Papers of Admiral Viscount Keith, Volume I (London, 1927), Elphinstone - Dundas, 21/3/1795, p. 248. 
secured his co-operation. Dundas displayed much trust in Elphinstone and Allardyce (Elphinstone's biographer) emphasises that his "natural capacity as a commander so strikingly manifested ... in the organisation of the expedition". ${ }^{17}$

Elphinstone hoisted his flag on the HMS Monarch (74) and his squadron of six ships (three third-rate ships of the line, a frigate, a sloop and a cargo ship) set sail for the Cape on 3 April. As the Army Commander, Major-General Alured Clarke and his troops were not yet ready, they only departed on 15 May with merchantmen to San Salvador where they had to await further orders. Elphinstone and Blankett rendezvoused off the Cape on 10 June 1795, but due to strong winds they sailed into False Bay the following day, arriving off Simon's Town at about 16:00. ${ }^{18}$

The defences of the Cape consisted of an extensive system of fortifications, a garrison, a Khoi regiment and the militia. The Castle in Cape Town was the main fortification, but as its effectiveness was doubtful, numerous smaller forts and batteries were erected around the Cape to create a system of defensive lines. In Camps Bay an entrenchment and a battery were erected and in Hout Bay three batteries were constructed. ${ }^{19}$ In total around 400 artillery pieces (some not properly mounted) and 19 ovens capable of producing 450 rounds of red-hot shot in 14 minutes, were available to defend the Cape Peninsula. ${ }^{20}$ Although many fortifications were far from formidable with a limited field of fire, the system of fortifications as a whole presented a major obstacle to any would-be attacker. A Dutch naval officer (Captain De Jong) considered it "formidable", stating that with 2500 soldiers to defend the Cape, it would be very difficult to take the Cape from the sea. ${ }^{21}$ However, in False Bay the defences were lacking and only two small batteries (armed with four 24pounders and four 4-pounders each) with a limited field of fire were erected in Simon's Bay (a good anchorage in a natural, sheltered bay). Hence, as the British knew (from intelligence reports and the many British warships and soldiers that regularly visited the Cape), False Bay was the ideal place for a hostile force to conduct a landing.

A. Allardyce, Memoir of the Honourable George Keith Elphinstone, p. 86. NAUK WO1/323, Journal of G.K. Elphinstone, June 1795, p. 263. Cape Archive Depot (hereafter CA) C714, Bijlagen, 27/2/1792, pp. 69-75 and H.F. Nel, Die Britse Verowering van die Kaap in 1795 (Unpublished MA, University of Cape Town, 1967), pp. 15-19.

CA C704, Bijlagen. Generale Staat van Ammunitie Goederen van Oorlog, November 1792, pp. 105-106.

C. de Jong, Reizen naar de Kaap de Goede Hoop, Ierland en Noorwegen, Volume II, (Haarlem, 1802), p. 84. 
The distressing news of the arrival of a British expeditionary force, reached A.J. Sluysken, Commissioner at the Cape and the highest politico-military authority, late on 11 June $1795 .{ }^{22}$ The Council of Policy of the Cape immediately dispatched Lt Col C.M.W. de Lille with 200 infantrymen and 100 artillerists to strengthen the Simon's Bay garrison of 110 infantrymen and 50 gunners. A call-up also went out for the burgher militia from the outlying districts to assist with the defence of the Cape (burghers between 16 and 60 were obliged to do military service), but the response was poor. ${ }^{23}$ By 1795 the Cape Garrison was a depleted force as the Württemberg Regiment, stationed at the Cape, had to leave for Batavia in 1792 due to the financial plight of the Dutch East India Company (VOC). The garrison consisted only of one regular infantry battalion (571 officers and men), the locally raised Pandoer Corps (about 200 strong), 57 infantrymen from depots of the Meuron and Württemberg Regiments, 44 sipahis (Malay infantry), an Artillery Corps (with 430 officers and men in total) as well as the burgher militia infantry and cavalry. The full-time soldiers amounted to roughly 1302 officers and men, while in total the defenders would not amount to much more than $3600 .^{24}$

As the Cape had no reliable news of the latest events in Europe, the Cape government faced a predicament. Britain and the Netherlands were allies, but the most recent information they received, suggested that the Netherlands could suddenly change sides. To complicate matters they could not count on the loyalty and support of the whole garrison and the burghers. The resolve and loyalty of the burgher population were weakened by internal strife and division as the interior was in turmoil and gross dissatisfaction existed with the VOC control of the Cape. Most of the burghers and soldiers supported the Dutch Patriotten and were opposed to the stadtholdership, while the officers and VOC officials were mainly loyal supporters of the Oranje Partij. The Garrison Commander, Colonel Robert Jacob Gordon, was an ardent Oranjeman known for his pro-British sentiments. As a result, the British assumed that he might welcome a British attack and that the garrison could be persuaded to change sides if Gordon was helped. ${ }^{25}$

On 14 June two British officers went to Cape Town to deliver the Prince of Orange's letter as well as a report by Elphinstone and Craig on the situation in the

22. CA C231, Resolutiën, 11/6/1795, pp. 130-132.

23. G.E. Cory, The Rise of South Africa (London, 1910), p. 56.

24. See CA VC75, P.W. Marnitz, Verhaal van de Overgaave van de Kaap de Goede Hoop aan de Engelshen door een Vriend der waarheid aldaar (Handwritten copy, 21/11/1796), pp. 33-35.; and H.F. Nel, Die Britse Verowering van die Kaap in 1795, pp. 23-25.

25. Records of the Cape Colony, I, Elphinstone Journal, pp. 58-60. 
Netherlands. ${ }^{26}$ The Council of Policy was divided because Gordon considered the British to be allies and wanted to welcome the British troops on provision that the Cape was held in the name of its lawful sovereign and the administration remained in control. ${ }^{27}$ Other members of the Council held the opinion that the British should not land at the Cape as the letter was signed by a fugitive prince in a foreign country, while their loyalty was to a country and not to a party. Eventually, the Council replied that British help in case of a French attack would be welcome, but that the Cape was capable of defending itself! ${ }^{28}$ Craig also visited Cape Town on 19 June in a further attempt to convince the Council to hand over authority, but Council again emphasised their commitment to defend the Cape and the lawful constitution of the Netherlands. ${ }^{29}$ The Dutch allowed British officers visiting the Cape to walk around, and they were able to provide valuable intelligence on the political and military situation in their dispatches. As Elphinstone stated in his journal, it was the duty of these officers to "gain as much intelligence possible". ${ }^{30}$

With an inadequate military force, Elphinstone complained to Dundas on 17 June that, since his force had no guns, mortars, artillerists, engineers or siege equipment, it would be very difficult to achieve success if the Dutch retreated behind their fortifications. ${ }^{31}$ Though negotiations still continued, it was already clear to Elphinstone that the Cape would not just be handed over to them, and on 18 June he dispatched the HMS Sphynx to San Salvador to summon Major General Clarke's force. ${ }^{32}$ The British were in a precarious position. Besides having insufficient force, they had no foothold ashore, there was a desperate shortage of water and provisions on some of the ships and many men were suffering from scurvy (187 on the Victorious alone). ${ }^{33}$ In the meantime, the Dutch allowed the sick to go ashore and they were placed under medical care, while the provisioning of the British squadron commenced. $^{34}$

26.

27.

28.

29.

30.

31.

32.

33.

34

CA C231, Elphinstone and Craig Report - Council of Policy, 13/6/1795 attached to Resolutiën, 13-14/6/1795, pp. 152-156.

CA C231, Resolutiën, 13-14/6/1795, pp. 165-166.

CA C231, Council of Policy - Elphinstone and Craig 14/6/1795, attached to Resolutiën, 13-14/6/1795, pp. 167-168.

Records of the Cape Colony, I, Council of Policy - Craig, 19/6/1795, p. 65.

NAUK WO1/323, Journal of G.K. Elphinstone, June 1795, pp. 254-255.

Keith Papers, I, Elphinstone - Dundas, 17/6/1795, p. 273.

W.G. Perin (ed.), Keith Papers, I, pp. 218 and 220.

Keith Papers, I, Elphinstone - Admiralty, 17/6/1795, p. 276.

P. Erskine, 'Admiral Elphinstone's Naval Task Force 1795-1796. The Memorabilia of the first British Occupation', in Antiques in South Africa, 12 (1983), p. 86. 
In a proclamation issued on 22 June Elphinstone and Craig directly appealed to the Cape citizens: they were offered British protection and invited to negotiate directly with the British. ${ }^{35}$ The Council of Policy was very perturbed about this. Soon afterwards negotiations with the British ceased, supplying the squadron stopped, while all horses, oxen and other draught animals were removed from Simon's Bay and Fish Hoek. On 28 June Elphinstone ordered three VOC ships at anchor in Simon's Bay "not to move from this place" ${ }^{\text {"36 }}$ and nine days later the British seized these ships. The Dutch protested, but due to the poor defences at Simon's Town they were powerless against an enemy like the Royal Navy (renowned for its crack gunnery). The Dutch evacuated the town during the night of 29 June and withdrew to Muizenberg. ${ }^{37}$ British supplies were getting less (from 2 July rations were cut by a third), and since negotiations failed, the British knew they would have to fight soon.

In the late eighteenth century, amphibious operations were difficult and the attacker was exceptionally vulnerable during the attempted landing as no specialised vessels were yet developed. Though Simon's Town would be difficult to hold in the face of a large-scale amphibious attack, its evacuation was a blessing for the British and its lack of proper defences was a grave Dutch military error. A crucial operational objective - to establish a beachhead on foreign soil - the British therefore easily achieved.

On the route from Cape Town to Simon's Town was Muizenberg, referred to as the "Thermopylae of the Cape Peninsula", a natural defensive position. Both Elphinstone and Craig realised the importance of Muizenberg as it had the high face of the Steenberg Mountain to the west and the Sandvlei (marshes) to the east, making a flanking movement virtually impossible. In their military planning, Elphinstone and Craig considered a flanking attack via Constantia, should they fail to take Muizenberg, but both reiterated that Muizenberg had to be taken. In preparation of an attack on Muizenberg, the Navy took soundings to establish if it would be possible for the ships to approach to within three-quarters of a mile from the beach. ${ }^{38} \mathrm{Naval}$ gunfire support was very important for an assault on Muizenberg. Elphinstone was

35. Records of the Cape Colony, I, Elphinstone and Craig - Dundas, 27/6/1795, p. 82.

36. Records of the Cape Colony, I, Proclamation by Elphinstone, 28/6/1795, p. 90 .

37. CA VC68, Brieven en Bijlagen, pp. 666-7 and C231, Resolutiën, 2/7/1795, pp. 378-380.

38. Keith Papers, I, Elphinstone Journal, 13 and 15/7/1795, pp. 334-335. 
concerned about the "shallowness of the water and the uncertainty of the wind" ${ }^{39}$ and about the effectiveness of his gunfire, as the long rolling swell would affect gunnery. But he reassured Craig that in right weather conditions ("a westerly wind with a smooth sea") his ships would be on their post within two hours. ${ }^{40}$ The landing of seamen with boats at Muizenberg was also considered, but was disregarded as the commanders were convinced that the Dutch would not stand. ${ }^{41}$

Muizenberg favoured the defender and the Dutch must have realised it was a crucial position, specifically as a number of military specialists have identified Muizenberg as a point of strategic value, because it controlled the link between False Bay and Cape Town. Good Dutch preparations and stubborn resistance would have made it very difficult for the British to take Muizenberg. Yet, only a portion of the Cape defenders (200 infantry, 120 artillery, 200 mounted burghers and 150 pandours $)^{42}$ were stationed here. Some of the Dutch artillery officers were concerned about the position and wanted to improve it, but Gordon thought it unnecessary as he considered the British to be friends. ${ }^{43}$ Furthermore, morale was low and the troops had no real trust in Gordon and in De Lille.

The British attack on Muizenberg commenced on 7 August with troops and two battalions of seamen (probably 1600 men) ${ }^{44}$ marching from Simon's Town, while four warships and a small gunboat sailed to Muizenberg. Though they lacked equipment and material, the British commanders were confident, and British fire drove the Dutch from their piquet at Kalk Bay, while ships bombarded Muizenberg with full broadsides, literally "thundering showers of shot" at the Dutch. ${ }^{45}$ Lieutenant Colonel De Lille, the Dutch commander at Muizenberg, and his infantry fled in great confusion, leaving everything except five field guns behind and retreated to Lochner's Farm. Only a few gunners conducted some sort of defence with two 24-pounders. Since these guns were not properly mounted, they embedded themselves into the sand and had to be redirected after every salvo, but the Dutch nevertheless secured a

39. Brenthurst Library (hereafter BL), MS 344/3, Viscount Keith Papers, Craig - Elphinstone, 17/7/1795.

40. Keith Papers, I, Elphinstone - Craig, 26/7/1795, pp. 336-338.

41. BL, MS 344/8. Memorandum, Craig - Elphinstone, 25/7/1795.

42. CA VC75, P.W. Marnitz, Verhaal van de Overgaave van de Kaap de Goede Hoop, p. 72 and H.F. Nel, Die Britse verowering van die Kaap in 1795, pp. 86-87.

CA VC75, P.W. Marnitz, Verhaal van de Overgaave van de Kaap de Goede Hoop, pp. 68-72.

44. Records of the Cape Colony, I, Elphinstone - Dundas, 18/8/1795, p. 114.

45. M. Boucher and N. Penn, Britain at the Cape, 1795-1803, Ross - Scott, 14/8/1795, p. 43. 
number of hits on the British warships. Eventually the artillerists were forced to retreat by the ships' broadsides. However, around the mountain and out of range of the ships' guns, some artillerymen and burghers made a stand and drove the British back to Muizenberg. ${ }^{46}$

After the action at Muizenberg, Elphinstone had much praise for the conduct of his men, referring to Craig's "... accustomed readiness and activity", adding that Blankett acted "... equally zealous". He also commended a number of other officers in his report to the Admiralty without expanding on his own role. ${ }^{47}$ In reports to higher headquarters, military commanders would often emphasise their own contribution to success. It was not, however, how Elphinstone reported on these events.

The poor Dutch defence astounded the British as the Muizenberg defences were not improved upon and De Lille retreated very quickly. Amongst the burghers there was much discontent, specifically when De Lille took a defensive position behind Sandvlei, just to retreat further to Wynberg, the moment Craig resumed his advance on 8 August. ${ }^{48}$ De Lille was removed from office as many in the Dutch camp called him a traitor and considered the defence of the Cape sabotaged. Probably due to their Orange sentiments, neither Sluysken nor Gordon nor De Lille made any significant effort to organise effective resistance before the withdrawal to Wynberg. Maj B.C. van Baalen, in charge at Wynberg, was also severely criticised while his commander, Gordon, never visited Wynberg to prepare for a British attack - he exerted himself in improving the Mouille Battery (Cape Town) on the north-west, while the real threat was in the south-east. ${ }^{49}$

The burghers perceived the Cape government as incapable of organising an adequate defence and believed that they themselves should now organise the defence

46. NAUK ADM51/1136, Journal of the Proceedings Commodore Blankett, see August 1795, CA VC75, P.W. Marnitz, Verhaal van de Overgaave van de Kaap de Goede Hoop, p. 303 and H.F. Nel, Die Britse verowering van die Kaap in 1795 , p. 90.

47. A. Allardyce, Memoir of the Honourable George Keith Elphinstone, p. 95.

48. CA VC76, H.D. Campagne, Memorie en bijzonderheden wegens overgave der Kaap de Goede Hoop 1795 (handwritten copy, 17/5/1797), pp. 52-3 and C.L. Neethling, Onderzoek van't verbaal van A.J. Sluysken, voormalige commissaris van Cabo de Goede Hoop, en verdediging van't gedrag der Caapsche burgery (place of publication not known, 1797), pp. 52-54.

49. CA VC75, P.W. Marnitz, Verhaal van de Overgaave van de Kaap de Goede Hoop, pp. 353-357. 
of the Colony. ${ }^{50}$ At a public Council of War meeting at the Burgerwaghuis in Cape Town on 11 August, Sluysken pleaded with the population to maintain order and assured them that the Cape would be defended as best as possible if everybody acted in unity. The following day, Elphinstone and Craig again requested Council to surrender the Cape, ${ }^{51}$ but the reply was that they would not give up while the Cape could still resist.

The British forces dug in at Muizenberg but, as the assaulting side, their hold was precarious. They needed supplies, equipment, reinforcements, field guns, cash and transport - without which their advance through the difficult terrain would have been extremely laborious. Their situation was alleviated by the Dutch lethargy. If the Dutch performed persistent, well-organised attacks on their beachhead, things would have been very difficult for them. When the East Indiaman Arniston arrived from St Helena Island on 9 August with 400 additional troops from the EEIC, nine field guns and cash, they were much relieved. ${ }^{52}$ Yet provisions and ammunition were still running very low despite Elphinstone's skilful administration of the shipboard stores. At a conference between the two commanders on 1 September, they resolved to wait another six days for Clarke. If he did not arrive, they would run the risk of battle or retire to the ships. In these "depressing circumstances [the] ... high spirit of the Admiral was one of the most essential services" and this was gratefully acknowledged by his colleagues. ${ }^{53}$

The Dutch military command was not convinced of the wisdom of an attack on the British position. Due to the insistence of the burghers and some artillery officers, Sluysken nevertheless ordered an attack. Yet, before it could take place, no doubt much to the relief of the British, a fleet of 14 British ships with General Clarke and the long awaited reinforcements sailed into False Bay on 3 September. ${ }^{54}$ British preparations for an attack commenced immediately and on 14 September they advanced on Wynberg with 4000 to 5000 men (including sappers and artillery).

The overwhelming British attack forced the Dutch to retreat, and as the situation seemed hopeless, Gordon and Sluysken stressed that the Cape could no

50. CA VC76, H.D. Campagne, Memorie en bijzonderheden wegens overgave der Kaap de Goede Hoop, p. 73.

51. CA C231, Resolutiën (Secrete), 12/8/1795, see Elphinstone and Craig Council of Policy, 12/8/1795.

52. $\quad$ BL MS 344/12. Craig - Elphinstone, 9/8/1795.

53. A. Allardyce, Memoir of the Honourable George Keith Elphinstone, p. 98.

54. NAUK ADM50/64, Admirals Journals, Vice Admiral Elphinstone, Monarch, 4/4/1795- 13/1/1797, 4/9/1795. 
longer be defended against the British. ${ }^{55}$ Negotiations commenced, Clarke agreed to a 24-hour truce at midnight on 14 September and the surrender documents was signed on 16 September. Many of the Dutch soldiers and burghers blamed their officers and specifically Gordon for the poor defence. As the situation was getting out of hand, the Dutch urged the British to come to their aid as soon as possible. ${ }^{56}$ On the same day the British occupied the batteries of the French line, while 1400 men marched into Cape Town. As the Dutch garrison marched out of the Castle to surrender, the soldiers jeered and swore at their officers, calling them traitors. ${ }^{57}$

The success of the Elphinstone expedition was to a great extent due to the fact that it was in accordance with Royal Navy wisdom concerning amphibious operations that had evolved since Elizabethan times. ${ }^{58}$ A first emphasis was on a careful and secret planning process, without which such endeavours could easily be jeopardised. Elphinstone's thorough preparation, planning, organisational skill and control of the expedition were crucial to its success. Effective co-operation between military and naval commanders was another vital prerequisite. In this respect, Elphinstone had a good working relationship with Craig. Their correspondence is proof of the open, co-operative spirit and emphatic trust that existed between them. Elphinstone's contemporaries furthermore saw him as an intelligent and benevolent commander and they respected his judgment. A further requirement was for both the political authority and the military commanders to have a clear understanding of what the objective was, since any deviation from the main purpose might have lead to ruin. The focus on the objective therefore had to be maintained until the operation had been completed. This was done. Originally Elphinstone and Craig thought that the Cape authorities would be willing to allow the British "in", but Elphinstone quickly realised that they had to use military force to achieve the objective. General Clarke was summoned from the previously agreed rendezvous point, while the assault on Muizenberg took place. When Clarke arrived, Wynberg was immediately attacked, which led to the Dutch capitulation.

British operations during the eighteenth century illustrated that the properly planned and executed exploitation of maritime power with amphibious operations can

55. CA VC76, H.D. Campagne, Memorie en bijzonderheden wegens overgave der Kaap de Goede Hoop, pp. 140-141.

56. CA VC75, P.W. Marnitz, Verhaal van de overgaave van de Kaap de Goede Hoop, p. 235.

57. C.J. Barnard, Robert Jacob Gordon se Loopbaan aan die Kaap, p. 428 verifies this account with reference to a number of contemporary sources.

58. S.W. Roskill, Strategy of Sea Power, pp. 28-29. 
lead to success "out of all proportion to the effort made". ${ }^{59}$ Though British efforts were augmented by Dutch mistakes, apathy and the poor Dutch morale, maritime power made the fast execution of the expedition possible, while through good command and control the objective was achieved. Britain therefore effectively utilised military power as a policy instrument.

The news of the capture of the Cape caused considerable relief at Whitehall. ${ }^{60}$ The First Lord of the Admiralty, Earl Spencer, referred to the Cape as a "very valuable acquisition ... obtained for this country at so little expense of lives and money ... one of the most advantageous we have ever made". ${ }^{61}$ Dundas congratulated Elphinstone on "... the surrender of Cape Town" and placing such an "... essential establishment under the dominion of Great Britain". ${ }^{2}$ The House of Orange is not mentioned and it is clear that the conquest was purely in the interest of Britain.

\section{Elphinstone and the defence of the Cape, 1795-96}

When Elphinstone and Clarke left for India on 15 November 1795, Craig became the first British Governor, while Blankett was appointed naval commander. Since many of the burghers in the interior supported the Batavian Republic and defied the British control in the hope of a Dutch or Dutch-French take-over, the new administration endeavoured to firmly establish British authority. Craig did much to improve the defences of the Cape against a possible French-Dutch assault. Many of the fortifications were upgraded, new fortifications were erected in Muizenberg and Simon's Town and Craig also retained a number of the regiments, on their way to India, at the Cape for a while. ${ }^{63}$

Elphinstone was convinced of the importance of the Cape to the imperial interest of Britain as well as of its value as a naval station. He called it a "desirable colony" and stressed in his correspondence to the Navy that the Cape had specific value for replenishing passing ships. ${ }^{64}$ To the Lords of the Admiralty he reported that

\footnotetext{
59. Ibid.

60. J. Holland Rose, William Pitt and the Great War (London, 1911), p. 254.

61. P. Erskine, 'Admiral Elphinstone's Naval Task Force 1795-1796. The

Memorabilia of the First British Occupation' in Antiques in South Africa, p. 88 .

62. NAUK WO 1/324, Dundas - Elphinstone, 16/1/1796, p. 483.

63. CA BO 146, Craig - Governor-general and Supreme Council of Bengal, 29 Aug 1796, p. 143 and U.A. Seemann, Fortifications of the Cape Peninsula, 1647-1829 (Cape Town, 1997), pp. 54-58 and 73-81.

64. Keith Papers, I, Elphinstone - Commissioners of Victualling, 23/9/1795, p. 374.
} 
if the Cape was a British naval station, ships could be repaired and replenished there and expeditions could rest there, but warned that though it might be important to shipping, the Cape's "safety “... must depend on the fleet ...". ${ }^{65}$ This was exactly how the War Ministry saw it: they emphasised to Craig that an "efficient Naval Force on that Station ..." was a prerequisite for the Cape's defence. ${ }^{66}$ In defending the Cape, the British saw the Royal Navy as the first line of defence, because a threat would come from the sea. Furthermore, if the Royal Navy maintained a presence at the Cape, it would enhance the maritime security of the empire. Dundas made it clear to Elphinstone that his principle attention in the Indian Ocean theatre (including the Cape) was to protect and secure the possessions Britain acquired from the enemy. ${ }^{67}$

During the era of the French Revolution and Napoleon, no other navy was equal to the British Royal Navy. It was proficiently run, had an effective administration with good ships, a larger body of sailors and was well led by competent and experienced officers. Due to constant improvements in training, gunnery, signals, equipment and tactics it never lost a major battle at sea and was able to project British power across the world. The Dutch and French Navies on the other hand lacked their former tactical and professional proficiency as their ability to maintain large fleets declined due to the fact that most of their aristocratic officers were removed. Though numerically the combined naval strength of France and her allies was superior to that of Britain, the French did not afford the same priority to maritime power, and did not appreciate the true global value of maritime power and a fleet as well as the British did. ${ }^{68}$

After news of the British conquest of the Cape reached the Netherlands, the Batavian Republic decided to attempt retaking the Cape with French support. ${ }^{69}$ In late January 1796, while Dutch ships were being fitted out at Texel, Britain received an intelligence report about a possible French-Dutch assault on the Cape. As every effort was made to maintain their new conquest, the frigate HMS Carysfort was dispatched

65. Keith Papers, I, Elphinstone - Spencer, 10/7/1796, p. 432.

66. Records of the Cape Colony, I, War Ministry - Craig, 14/2/1796 pp. 326327.

67. NAUK WO 1/324, Dundas - Elphinstone, 16/1/1796, p. 488-489.

68. For a comparison of the navies of Britain and her enemies, see S.W. Roskill, Strategy of Sea Power, p. 65; R. Harding, Seapower and Naval Warfare (London, 2003), p. 261; A.T. Mahan, The Influence of Sea Power upon the French Revolution and Empire, I (London, 1892), pp. 74-75; T.H. Milo, De Geheime Onderhandelingen tusschen de Bataafsche en Fransche Republieken van 1795 tot 1797 (Den Helder, 1942), pp. iv-vii. 
on 23 February to warn the Cape (she arrived on 23 April), while additional warships and military reinforcements also left for the Cape. In the meantime Elphinstone was on his way back from India (with five ships), arriving in False Bay on 23 May. On 28 May the first reinforcements from Britain, three warships with the $78^{\text {th }}$ Regiment onboard, arrived at the Cape. Within months (between 28 May and 2 August) Britain reinforced the Cape with another six warships, troopships, cargo ships and more than 5000 troops dispatched over a distance of about 7000 miles. $^{70}$ By the end of July, the British had around 8400 troops at the Cape, while they were still expecting another 1000 men that were on their way to the East, which pushed up the potentially available force to 9400 in total. ${ }^{71}$ Elphinstone was very confident and thanked the Admiralty, emphasising that with such reinforcements the Cape was "... in a naval and military view beyond insult by any force our enemies can send out". ${ }^{72}$

The Dutch squadron (eight warships and one cargo vessel) was under the command of Rear Admiral Engelbertus Lucas. The squadron was destined for the Cape of Good Hope and the East Indies and had clear orders to retake the Cape with French support. ${ }^{73}$ It departed from Texel on 23 February 1796 and sailed north around Scotland and put into La Luz in the Grand Canary on 13 April 1796. Before putting into La Luz a British frigate, the HMS Moselle (Captain Brisbane), on convoy duty with two transports to Barbados, sighted the Dutch squadron. Brisbane shadowed the squadron for a while and then decided to let his convoy proceed alone, while he made haste for the Cape to warn Elphinstone. Elphinstone appreciated the news and Brisbane's diligence, because he now had certainty about the whereabouts of the Dutch squadron. $^{74}$

In the meantime a French squadron under Rear Admiral De Sercey (4 frigates) rounded the Cape en route to Mauritius. Elphinstone did not meet them at sea, but one of his frigates, the HMS Sphynx (24), under the command of Captain Brisac, crossed paths with De Sercey's squadron south-east of the Cape on 25 May. The French frigate Régénérée (36) immediately tried to engage the Sphynx, but Brisac

70. C.J. de Villiers, Die Britse Vloot aan die Kaap, pp. 69-71.

71. Records of the Cape Colony, I, Craig - Dundas, 30/7/1796, p. 416.

72. Keith Papers, I, Elphinstone - Spencer, 10/7/1796, p. 431.

73. NAN 1.01.08 - 4795, Secr Res van HH Mog van 1 Jan 1795 - Ult Febr 1796. Instructie voor den kapitein ter zee E. Lucas, commandeerende s'Lands schip van oorlog Dordrecht, 18/11/1795, p. 755. These orders, with little change are also in NAN Marine, 1795-1813, 2.01.29.01 - 442, Secrete Notulen en Bijlagen van het Committé tot de Zaken van de Marine, May December 1795.

74. $\quad$ T.H. Milo, De Geheime Onderhandelingen tusschen de Bataafsche ...", p. 158 and The Keith Papers, I, Elphinstone - Admiralty, 3/8/1796, p. 437. 
realised he was outgunned and made a run for the Cape, being hotly pursued by the Frenchmen. Sphynx used all her available canvas and even threw most of her guns overboard, yet she just managed to outrun her hunter and arrived at the Cape two days later. Elphinstone now also knew that De Sercey had gone to Mauritius and did not join Lucas. ${ }^{75}$ De Sercey arrived at Mauritius in June 1796 and bolstered the French force consisting of frigates and corvettes (ideal vessels for privateering). These ships were a problem to British shipping in the Indian Ocean, but as Elphinstone's first priority was to defend the Cape against the eminent threat Lucas's squadron posed, he did not pursue De Sercey.

After a voyage of more than five months, the Dutch squadron anchored in Saldanha Bay on 6 August $1796 .^{76}$ In much need of fresh supplies, with very little water on board, many ill crewmen and much dissent on a number of ships, Lucas's squadron was not exactly in its best fighting trim. Furthermore, Lucas still held onto a mistaken belief that French help was forthcoming, which would make the reoccupation of the Cape a possibility. Lucas tried to gain intelligence concerning the British force, but despite warnings from locals that they had a force superior to his and that he had to leave immediately, the Dutch took down their sails to be repaired. ${ }^{77}$

During this period Elphinstone and Craig again displayed their good working relationship, commitment, vigour, organisational ability and relentless pursuance of duty. When Craig received the news on 3 August that ships were seen off the coast in the vicinity of Saldanha Bay, he immediately dispatched Lt McNab with cavalry to Saldanha Bay. Elphinstone was also notified and their common wisdom was that the Dutch ships might sail south, rounding the Cape at a distance in order to miss the strong British squadron. As a result of urgent repairs to ships and a strong south-easterly wind Elphinstone's squadron departed on 6 August searching "... to the Southward and West, in expectation of [the Dutch] having taken that course". 78

75. The Sphynx was escorting a ship it had captured (the American Elya), but had to give up the prize as they were outgunned and had to make a run for False Bay. See CA A455, Henry Dundas Collection, Elphinstone - Dundas, 6/7/1796; and Keith Papers, I, Elphinstone - Admiralty, 24/6/1795, pp. 420421.

76. NAN 2.01.29.03.28, NAN 2.01.29.03.28, J.J. Melvill, Journaal gehouden ... aanboord van s'Lands schip Dordrecht ..., 5/4/1795 to 18/8/1796, see 7/8/1796.

77. NAN 2.01.29.03.44. E. Lucas, Journaal gehouden aan boord van s'Lands schip Dortrecht ...; and T.H. Milo, De Geheime Onderhandelingen tusschen de Bataafsche ..., pp. 177-187. 
On the day Elphinstone left, McNab confirmed that nine Dutch ships were indeed anchored in Saldanha Bay. Craig, fearing a Dutch landing and movement into the interior, issued a series of proclamations that prohibited (under the death penalty) any contact with the Dutch. All farmers within 10 hours of Saldanha Bay were ordered to take their cattle and horses into the interior and no fishing vessels were allowed to depart. ${ }^{79}$ On 13 August Dutch reconnaissance parties reported about 600 British soldiers (Craig's vanguard) on their way to Saldanha Bay. Some of his officers urged Lucas to depart immediately for Mauritius. However, Lucas's council of war decided on 14 August not to leave before they finished watering the ships for a voyage of at least six weeks. ${ }^{80}$

Elphinstone was at sea, searching for his enemy, in "the most tempestuous weather [he] ever experienced". ${ }^{81}$ The squadron arrived back in Simon's Bay on 12 August with storm damage to most ships. This futile search clearly illustrates the point that in warfare at sea defence is the weaker action, since the defender's attempts to block a whole coast or part of it, is an enormous undertaking. If the defender disperses his force too much, he would be weaker and could be defeated in detail, which is contrary to the principles of war.

When Elphinstone learned that the Dutch were at anchor in Saldanha Bay, he wished to leave immediately to prevent them from escaping. Bad weather, however, prevented his departure and he wrote to Craig, "it blows so strong we cannot immediately get out as is my intention". ${ }^{82}$ On 13 August, due to the fierce gale, numerous ships dragged their anchors, the Crescent beached, the Trident hit a rock and the Tremendous was nearly lost as both her anchors dragged. Elphinstone referred to it as the "... most anxious moments of my life" but the next day urgent repairs continued to prepare the ships for sea. ${ }^{83}$ When the wind allowed it on 15 August, Elphinstone immediately put to sea with 14 ships (seven ships of the line) ${ }^{84}$ arriving

79. See the various Proclamations by Craig in CA BO171, 7/08/1796, pp. 1101; BO147, 11/08/1796, p. 228; and BO160, Day Book, 9/08/1796, p. 49.

80. J.C. Mollema, Geschiedenis van Nederland ter Zee, III (Amsterdam, 1941), p. 375; and T.H. Milo, De Geheime Onderhandelingen tusschen de Bataafsche ..., pp. 187-191.

81. NAUK WO1/325, Elphinstone - Nepean, 19/8/1796, pp. 561-562.

82. CA BO 147, Elphinstone - Craig, 12/8/1796, p. 229.

83. Keith Papers, I, Elphinstone - Admiralty, 19/8/1796, pp. 454-455.

84. Though many sources state that there were 13 ships, the naval record suggest Elphinstone had 14 ships altogether. See NAUK ADM50/65, Proceedings of the Squadron under the Command of Thomas Pringle Esq., 
at Saldanha Bay the next day "with all ... sails crowded advancing with a fair wind directly to the mouth of the harbour". 85

In the meantime Craig's main force of 2500 soldiers and 11 guns had marched to Saldanha Bay on 14 August 1796 (he had left 4000 troops in Cape Town) and arrived before noon on 16 August. When Elphinstone's squadron arrived in the late afternoon they effectively blocked the entrance to Saldanha Bay. He sent an officer to Lucas requesting that the Dutch surrender "... to spare an effusion of blood ... otherwise it will be my duty ... of making serious attack ... the issue of which is not difficult to guess". ${ }^{86}$ Lucas (with only two ships of the line, three large frigates, three smaller warships and one transport vessel) was completely outgunned. There was much dissent amongst his officers and many of the Dutch crews were in a virtual state of mutiny. ${ }^{87}$ It was not possible to slip past Elphinstone's ships and if he risked a battle with his smaller vessels, they would be no match for Elphinstone's action-ready squadron. He therefore conveyed his decision to surrender on 17 August. $^{88}$

Without French assistance, the Lucas expedition was a sad affair that was doomed. The Dutch failed to grasp and apply the conventional wisdom concerning expeditions to a foreign soil, so well understood by the British: ${ }^{89}$ They lost secrecy in planning the expedition, organisationally they were not adequately prepared and without French support their fleet was too weak to retake the Cape. The well-known British naval theorist Admiral Colomb emphasised that such expeditions had to be accompanied by overwhelming naval force to achieve command of the sea as well as sufficient troops to make attacks successful. ${ }^{90}$ The Lucas expedition failed on both accounts. Due to much dissent and ill discipline, decision-making processes were

\footnotetext{
Rear Admiral of the Red, for the period 24/8/1795 to $19 / 5 / 1798$, see 13 to $15 / 8 / 1796$.

85. Records of the Cape Colony, Craig - Dundas, 19/8/1796, pp. 138-139.

86. Keith Papers, I, Elphinstone - Lucas, 16/8/1796, pp. 440-441.

87. Instituut voor Maritieme Historie, Milo120, Diverse scheepsjournalen, $\mathrm{Hr}$ Ms Revolutie, Dordrecht, Castor, Bellona, Havik, Vrouw Maria, Braave en Cyrion, dd 1796, Havik, see 15/8/1796 to 18/8/1796.

88. See NAN 2.01.29.03.44, E. Lucas, Journaal gehouden aan boord van s'Lands schip Dordrecht door den Capitein Engelbertus Lucas commandeerende 'slands esquader naar de Ost Indien, 25/1/1796 18/8/1796; and J.C. Mollema, Geschiedenis van Nederland ter Zee, III, pp. 376-377.

89. S.W. Roskill, Strategy of Sea Power, pp. 28-29.

90. P.H. Colomb, Naval Warfare, Its Ruling Principles and Practice HistoricallyTreated (London, 1891), pp. 219-220.
} 
often cumbersome and a waste of time. Furthermore, in terms of the political will and the ability of the military commanders to achieve their objectives, the expedition was a failure.

Elphinstone did not only conquer the Cape, but he actively defended it and commended its value to the British Government. When Elphinstone handed over his responsibilities to his successor, Rear Admiral Thomas Pringle, he provided Pringle with a detailed account of his new command, his ships and material, the type of problems he would have to face and the duties he would have to perform. Furthermore, he also explained the greater strategic situation to Pringle. Pringle, however, did not share Elphinstone's enthusiasm for the Cape and expressed his disenchantment with this "part of the world [that] ... produces nothing new, at least nothing pleasant...", stating that it is in hell where "... the Scoundrel is that discovered this cursed place". 91

Elphinstone returned to Britain on 7 October 1796 . He was not only the conqueror of the Cape, but also conducted the maritime defence of the Cape with vigour and was able to capture the Dutch fleet intact. By actively seeking out and destroying his enemy, he confirmed British control of the Cape and illustrated to Britain's enemies the virtual impossibility of taking back the Cape with force of arms. He was hailed as a hero in Britain and was created Baron Keith in the peerage of Ireland. As always in the colonial struggles between Britain and her European rivals, sea power ultimately decided the outcome. ${ }^{92}$ The Royal Navy's ability to contain her enemies' fleets within European waters and to punish them severely whenever they emerged from port in this case turned the scale and determined the fate of the Cape. In essence, it was British sea power and the lack of a comparable ability amongst her opponents that facilitated the British conquest.

\section{The later naval career of Lord Keith}

At the close of 1798, Lord Keith was appointment Second in Command to the Earl St Vincent in the Mediterranean and soon assumed command due to St Vincent's illness. This brought Lord Keith in conflict with Britain's famous naval hero, Horatio Nelson, who considered Keith's appointment as a snub to himself, but Keith was twelve years older than Nelson and three years his senior as an admiral. In Nelson Keith had a difficult subordinate, who at times ignored his orders and held him

91. BL MS 376/6, Pringle - Elphinstone, 3/5/1797.

92. P.M. Kennedy, The Rise and Fall of British Naval Mastery (London, 1986), p. 129 . 
in open contempt. Because Nelson thought himself, not Lord Keith, the better man to command the Mediterranean, he had no feeling of cordiality towards Keith. ${ }^{93}$ Nelson perceived Keith as lofty, stating in a letter to Captain Troubridge that "we ... are not equal to Keith in his estimation and ought to think it an honour to serve under such a clever man" ${ }^{94}$ Nelson's biographers refer to Keith a "quiet, dour, old-fashioned Scot", while Keith for his part was shocked by the situation at the Court of Palermo, its allurements, Nelson's function there and his relationship with the Hamiltons, specifically Lady Emma Hamilton. Keith referred to it as "... fulsome Vanity and Absurdity ...". ${ }^{95}$ But it is to Keith's credit that when Nelson did not obey him, he insisted on compliance and "bore [Nelson's] refractoriness with dignified patience". When Nelson left the Mediterranean for Britain with Sir William and Lady Hamilton in June 1799, Keith's relieve was obvious and he could not spare some sarcasm, stating that "Lady Hamilton has had command of the Fleet long enough". 96

Not only did Keith acquire a fortune through prize money in his naval career, but also received good promotion. In 1799 he was promoted to Vice Admiral of the Red, he became an Admiral of the Blue in 1801, Admiral of the White in 1805 and Admiral of the Red in 1810. Between 1803 and 1807 Keith was Commander-inChief in the North Sea. When Napoleon amassed a huge invasion fleet at Boulogne and in the Low Countries, Keith's squadron (and others) constantly harried and raided the invasion ports. ${ }^{97}$ In February 1812, Keith was appointed Commander-in-Chief of the Channel Fleet and in 1814 he became a Viscount. When Napoleon surrendered to the British after Waterloo (July 1815), it was to a ship under Keith's command, the HMS Bellerophon (Captain Maitland). Napoleon was brought to England and the decisions of the British government were expressed through Keith to the fallen Emperor. Keith was not impressed by his celebrated prisoner or the vanity of Napoleon and his entourage. He refused to be part of any disputes and coldly maintained that he was just obeying orders. Keith died on 10 March 1823 at Tullyallan, his property in Scotland.

93. R. Southey, The Life of Nelson (London, 1911), p. 198.

94. D. Howarth and S. Howarth, Nelson. The Immortal Memory (London, 1988), p. 217.

95. D. Howarth and S. Howarth, Nelson, p. 226.

96. A.T. Mahan, The Life of Nelson. The Embodiment of the Sea Power of Great Britain (London, 1899), pp. 364 and 437.

97. S. W. Roskill, The Strategy of Sea Power, p. 77. 


\section{Conclusion}

After the Netherlands and Spain became allies of France in 1795, the alliance provided the French with a series of bases, literally around the world. Yet, this quickly changed. Despite the fact that the first three years of the War of the French Revolution saw few naval actions, Britain acted quickly and occupied a number of these bases (the Cape of Good Hope and Ceylon being the ones of most strategic importance) to avert the threat to India. Indeed, during this conflict the remark Lord Palmerston would make a few years later (1840) rang true: "Every country that has towns within cannon shot of deep water will remember the operations of the British Fleet ... whenever such country has any differences with us". ${ }^{98}$ It was the Royal Navy with commanders like Nelson, Hood, St Vincent, Elphinstone (Lord Keith) and many more that, above all, secured the imperial interest of Britain and protected the little island against its powerful continental enemies.

Elphinstone was very successful at the Cape and served British interests well. The conquest of the Cape was a great success and brought much relief to the British government and powerful British commercial interests, such as the EEIC. Elphinstone's ships patrolled the surrounding oceans and supported the Royal Navy squadron in India, and when the ill-fated Lucas expedition appeared off the Cape, he effectively neutralised the threat. Thereby he illustrated to Britain's enemies that Britain was prepared to act with impunity against any endeavour to take the Cape with force or to threaten her maritime interest - even in the furthest corners of the world. When the Cape was returned to the Netherlands for a short while (from 1803 to 1806, when Britain conquered it for a second time), it was in accordance with the conditions of the Peace of Amiens and not because the victory of 1795 was incomplete.

Naval command during the eighteenth century was demanding in the sense that commanders had to have a clear strategic grasp and had to be able to make independent command decisions, often in the furthest corners of the world. Due to the distance from Britain, command at the Cape had certain advantages and disadvantages. On the one hand it was often difficult to make important decisions without prior consultation with higher authorities, while on the other hand, commanders had more freedom of action as regards operational and logistic matters. In terms of policy and strategic matters, Elphinstone did consult with the British government as far as possible, but he often had to make independent decisions at short notice. Good examples are his timely decision to go for the military option in subduing the Cape and summoning Clarke. Furthermore, his decision to depart from 


\section{2}

India and to concentrate his force at the Cape was correct as he judged this threat the higher strategic priority.

Amphibious expeditions are dependent on command of the sea or at least an overwhelming naval force, ${ }^{99}$ while good intelligence and co-ordination between various elements of joint forces are also essential for success. Elphinstone and Craig went to much trouble to gain intelligence and immediately shared it with each other. The fact that both wanted the other to be as informed as possible, reflects the good cooperative spirit that existed between the two commanders. In comparing the Elphinstone and Lucas expeditions to the Cape, the most striking feature is perhaps that Elphinstone had overwhelming force, Lucas not.

Though some shots were exchanged, no naval battle took place between the two squadrons. The Royal Navy was the superior force due to its tactical and operational skills, good leadership, strong tradition, professionalism, confidence, experience and discipline. In contrast the Dutch were undetermined due to political interference in the functioning of their navy, the disruption caused by the revolution and the rapid political change in the Netherlands. Dutch discipline was poor, they lacked experience and their leadership was ineffective. Lucas might have stood a chance to escape in the heavy sea conditions if he had put to sea and ran for Mauritius. But due to his inactivity and command and control problems, he remained in Saldanha Bay and was forced to surrender.

Elphinstone saw much action during his naval career, but he never fought a pitched battle at sea involving large fleets. Nonetheless, he reached the highest rank and occupied some of the most responsible posts in the navy. This was probably due to his ability as an administrator and a negotiator, the energy he displayed in pursuing his duty and the trust his superiors placed in his ability to make the right command decisions. His administrative and organisational skills as a commander were clearly illustrated in his thorough preparations for the Cape expedition as well as his control during the campaign. When the navy had to act, he energetically prepared and applied his ships, getting them ready for action and exerting himself to find and neutralise the enemy. Considering the distance from Britain, Elphinstone maintained extremely good and regular communication with the Admiralty and the British Government, often dispatching ships with special messages. He kept his superiors informed about his decisions, explaining what alternatives existed and why he had chosen a specific course of action.

99.

P.H. Colomb, Naval Warfare, p. 220. 


\section{3}

In order to do justice to Elphinstone, the last word should perhaps be given to Mahan who refers to Elphinstone as "one of the most efficient and active of the generation of naval officers between St Vincent and Nelson". 100

\section{Bibliography}

\section{Primary Sources}

\subsection{The Cape Archive Repository}

\subsubsection{VOC Archive}

C231, Proceedings and Resolutions (Resolutiën) of the Council of Policy at the Cape of Good Hope with Attachments, 1795.

C231, Secret Resolutions (Secrete Resolutiën) of the Council of Policy at the Cape of Good Hope with Attachments, 1795.

C704, Report with Annexures, Nederburgh and Frijkenius (Bijlagen) 24/7/1793.

C714, Report with Annexures, Nederburgh and Frijkenius (Bijlagen) 10/9/1793.

\subsubsection{First British Occupation}

BO146, Letter Book, June 1795 - May 1797.

BO147, Letter Book, February 1796 - August 1796.

BO160, Day Book, December 1795 to December 1797.

BO171, Proclamations, Origineel Placaat Boek, September 1795 - August 1796.

\subsubsection{Verbatim Copies}

VC68, Brieven en Bylagen van den Commissaris te Cabo de Goede Hoop, A.J. Sluysken, 1793-1796.

VC75, Marnitz, P.W, Verhaal van die Overgaave van de Kaap de Goede Hoop aan de Engelshen door Een vriend der waarheid aldaar. In't tweed jaar der Batavische Vrijheid, 21 November 1796 (handwritten copy).

VC76, Campagne, H.D., Memorie en bijzonderheden wegens overgave der Kaap de Goede Hoop 1795, 17/5/1797 (handwritten copy). 
VC76, Neethling, C.L., Onderzoek van't verbaal van A.J. Sluysken, voormalige commissaris van Cabo de Goede Hoop, en verdediging van't gedrag der Caapsche burgery (place of publication not known, 1797).

\subsubsection{Non-Public Records (Private Collections)}

A455, Henry Dundas Collection.

\subsection{Nationaal Archief Nederland}

\subsubsection{Archive of the States-General (Staten-Generaal)}

1.01.08 - 4795, Secr Res van HH Mog van 1 Jan 1795 to Ult Febr 1796, $15 / 12 / 1795$.

1.01.08 - 4795, Secr Res van HH Mog van 1 Jan 1795 to Ult Febr 1796. Instructie voor den kapitein ter zee E. Lucas, commandeerende s'Lands schip van oorlog Dordrecht, 18/11/1795.

\subsubsection{Archive of the Department of the Navy (Departement van Marine), 1795-1810}

2.01.29.01 - 442, Secrete Notulen en Bijlagen van het Committé tot de Zaken van de Marine, May - December 1795.

2.01.29.03.28, J.J. Melvill, Journaal gehouden door den ondergetekende gediend hebbende as $1^{\mathrm{e}}$ officier, Capt en daarna als Capitein bij de Vlag onder den Schout by Nagt Engelbertus Lucas aanboord van s'Lands schip Dordrecht gemonteerd met 66 stukken canon bemand met 450 koppen, 5/4/1795 - 18/8/1796.

2.01.29.03.44, E. Lucas, Journaal gehouden aan boord van s'Lands schip Dordrecht door den Capitein Engelbertus Lucas commandeerende 'slands esquader naar de Ost Indien, 25/1/1796 - 18/8/1796.

\subsection{National Archive of the United Kingdom}

1.3.1. Records of the Admiralty, Naval Forces, Royal Marines, Coastguard, and related bodies

ADM50/64, Admirals Journals, Vice Admiral Elphinstone, Monarch, 4/4/1795 - 13/1/1797.

ADM50/65, Admirals Journals, Proceedings of the Squadron under the Command of Thomas Pringle Esq, Rear Admiral of the Red, for the period 24/8/1795 - 19/5/1798. 
ADM51/1136, Captains Logs, Journal of the Proceedings of His Majesty's Ship America, Commodore Blankett Commander, 16/2/1795 - 27/1/1797.

\subsubsection{Records created or inherited by the War Office, Armed Forces, Judge Advocate General, and related bodies}

WO1/323, Cape of Good Hope, Papers on the Expedition to take the Cape, Dispatches from its Commanders, January - October 1795.

WO1/323, Journal of G.K. Elphinstone, 1795.

WO1/324, Cape of Good Hope, Dispatches from the Commandant, October - December 1795.

WO1/325, Cape of Good Hope, Dispatches from the Commandant, 1796.

\subsection{Instituut voor Maritieme Historie}

F.E.J. Milo Collectie, Milo120, Diverse scheepsjournalen, Hr Ms Revolutie, Dordrecht, Castor, Bellona, Havik, Vrouw Maria, Braave en Cyrion, dd 1796 , Havik, see $15 / 8 / 1796$ to $18 / 8 / 1796$.

\subsection{Brenthurst Library}

MS 344/3, Viscount Keith Papers, Craig - Elphinstone, 17/7/1795.

MS 344/8. Memorandum, Craig - Elphinstone, 25/7/1795.

MS 344/12. Craig - Elphinstone, 9/8/1795.

MS 376/6, Pringle - Elphinstone, 3/5/1797.

\subsection{Published Archival Sources}

Eybers, G.W. (ed.), Select Constitutional Documents Illustrating South African History, 1795-1910 (New York, 1918).

Perin, W.G. (ed.), The Keith Papers. Selected from the Letters and Papers of Admiral Viscount Keith, Volume I (London, 1927).

Theal, G.M. (ed.), Records of the Cape Colony from 1793 to December 1796, Volume I (London, 1897). 


\section{Secondary Sources}

\subsection{Theses}

Barnard, C.J., Robert Jacob Gordon se loopbaan aan die Kaap (MA, US), in C. Beyers, et al (eds.), Archives Year Book for South African History, 13(1) (Parow, 1950).

De Villiers, C.J., Die Britse Vloot aan die Kaap, 1795-1803 (MA, UCT, 1967).

Nel, H.F., Die Britse verowering van die Kaap in 1795 (MA, UCT, 1967).

\subsection{Books and Articles}

Allardyce, A., Memoir of the Honourable George Keith Elphinstone, K.B., Viscount Keith, Admiral of the Red (Edinburgh, 1882).

Blumenson, M. and Stokesbury, J.L., Masters of the Art of Command, (Boston, 1975).

Boucher, M. and Penn, N. (eds.), Britain at the Cape, 1795-1803 (Houghton, 1992).

Cory, G.E., The Rise of South Africa (London, 1910).

Colomb, P.H., Naval Warfare, Its Ruling Principles and Practice Historically Treated (London, 1891).

De Jong, C., Reizen naar de Kaap de Goede Hoop, Ierland en Noorwegen, in de jaren 1791 tot 1797, Volume II (Haarlem, 1802).

Directorate of Naval Staff Duties, The Fundamentals of British Maritime Doctrine (London, 1995).

Erskine, P., 'Admiral Elphinstone's Naval Task Force 1795-1796. The Memorabilia of the first British Occupation', in Antiques in South Africa, 12 (1983).

Foster, S., Hit the Beach. The Drama of Amphibious Warfare (London, 2004).

Grove, E. (ed.), Great Battles of the Royal Navy (London, 1994).

Harding, R., Seapower and Naval Warfare (London, 2003).

Holland Rose, J., William Pitt and the Great War (London, 1911).

Howarth, D. and Howarth, S., Nelson. The Immortal Memory (London, 1988).

Kennedy, P.M., The Rise and Fall of British Naval Mastery (London, 1986). Mahan, A.T., The Influence of Sea Power upon the French Revolution and Empire, 1793-1812, Volume I (London, 1892).

Mahan, A.T., The Life of Nelson. The Embodiment of the Sea Power of Great Britain (London, 1899). 


\section{7}

Milo, T.H., De Geheime Onderhandelingen tusschen de Bataafsche en Fransche Republieken van 1795 tot 1797 (Den Helder, 1942).

Mollema, J.C., Geschiedenis van Nederland ter Zee, Volume III (Amsterdam, 1941).

Roskill, S.W., The Strategy of Sea Power. Its Development and Application (London, 1962).

Seemann, U.A., Fortifications of the Cape Peninsula, 1647-1829 (Cape Town, 1997).

Southey, R., The Life of Nelson (London, 1911). 